\title{
Psychopathic disorder: a category mistake?
}

\author{
Colin A Holmes Deakin University, Australia
}

\section{Author's abstract}

Although the concept of psychopathy retains its currency in British psychiatry, apparently being meaningful as well as useful to practitioners (1), it is often taken to refer to a purely legal category with social control functions rather than a medical diagnosis with treatment implications. I wish, in this brief article, to suggest that it is essentially, and most usefully, an ethical category which stands outside the diagnostic framework of present-day psychiatry.

\section{The clinical background}

Even in clinical contexts, the existence of a type of individual who does not regard others as having moral claims upon him, or her, has long been recognised. In modern psychiatry the idea is closely linked to the development of the concept of moral insanity which took place during the eighteenth century. Although at that time, as Werlinder (2) reminds us, the term 'moral' had nuances of meaning relating to the feelings, or passions, rather than to ethics, it seems that alienists sometimes used the term ambiguously, and quite often specifically to mean 'ethical'. Benjamin Rush, often credited with the first attempt to explicate the concept of moral insanity, is a case in point, referring to 'diseases of the moral faculty defined as a power to distinguish and choose between good and evil' and coining the term 'anomia' to include all cases in which there was a total absence of conscience (3).

In Britain, a distinction was sometimes made between the terms 'moral' and 'medical', and between 'moral' and 'mental'. Cases of disregard for prevailing moral norms were subsumed in Prichard's 1835 concept of moral insanity (4), and whilst he did not intend that morality be completely annexed by medicine he certainly wanted the boundaries between them to be moved so that some aspects of behaviour hitherto regarded as forms of depravity would fall into the category of moral insanity. He stressed that true moral depravity and moral insanity were quite distince, however, on the grounds of the 'undoubted' corporeal

\section{Key words}

Moral insanity; psychopathy; psychopathic disorder; mentally abnormal orfender; sociopathy. origin of the latter, though in fact causal distinctions of this subtlety could not be empirically substantiated (5).

An even more explicit example of this equation of the 'moral' in moral insanity with 'ethical' is provided in the work of John Kitching, Superintendent of York Retreat, in his Lectures of 1857 (5), which actually contrast 'moral' with 'affective' insanities. The morally insane individual, Kitching says, is abnormal only in respect of his lack of moral scruple, and he hints at the possibility of the 'successful psychopath' when he says that examples may be found from 'the circle of our own acquaintance', and refers to 'the unregulated ambition and unscrupulous daring of clever and gifted men, in which nature had implanted excellent powers of mind, but left them unfurnished or scantily provided, with the controlling and humanising faculties of an equally powerful moral constitution' (7).

Writing in 1874, Maudsley suggested that the morally insane individual:

'has no capacity for true moral feelings; all his impulses and desires, to which he yields without check, are egoistic; his conduct seems to be governed by immoral motives ... there is an amazing moral insensitivity ... they often display an extraordinary ingenuity in explaining, excusing or justifying their behaviour, exaggerating this, ignoring that, and so colouring the whole as to make themselves appear the victim of misrepresentation' (8).

Maudsley's use of the term 'moral' here is unequivocal, and formed the conceptual foundation, via the work of Tredgold, for the relevant parts of the British Mental Deficiency Act of 1913. Indeed, Tredgold's 1908 textbook on mental deficiency became a standard work and has continued to be revised and reprinted to the present day. In the first edition, and even more so in the second, 'moral deficiency' is framed in terms of an inadequate development of the moral sense, meaning 'the faculty of appreciating the obligations due from man to his neighbours as component units of society' (9). It was this 'clinical' concept, such as it was, which entered into the Act of 1913 and enabled legal and medical authorities to collaborate in the social control process; it is tempting to believe that the formulations of these two institutions, actually unmistakably 
ethical, coincided largely for reasons of mutual convenience rather than as a reflection of contemporary empirical knowledge (10).

In America, nineteenth century opinion became sharply polarised on the questions whether moral insanity was just another name for depravity, whether it was truly an illness, whether it had any exculpatory force in morals or in law, and whether it referred, in any case, to ethical or affective disorders. The whole issue is examined in detail by Fink (11). John Gray, a leading alienist and editor of the American fournal of Insanity, took the view that if a man knew the difference between right and wrong then he should be regarded as a bad man rather than a mad man, and he used the journal as a mouthpiece for this view over a number of years from $1850(2,11)$. The important point is that he regarded the 'moral insanity' concept against which he was railing to refer to an absence of moral scruple rather than an affective or impulsive disorder. A host of leading American authorities, including Spitzka, Bowers, Nascher and Wholey, championed this approach, focusing on the failure of the individual to utilise concepts of moral right and wrong, and their views are discussed by Fink (11) in some detail.

The influence of European degenerationists, especially Lombroso, is apparent in the American accounts and the concept of the 'born criminal' is particularly significant. Although conceived by Lombroso as a person without moral sense, and tending to fall foul of the law as a result, he is not predisposed to commit crime per se (12). Like the psychopath, as I have portrayed him elsewhere (13), he is devoid of any sense of personal moral responsibility, and of the commonly associated emotions such as remorse and empathy. His observance of social and legal rules is merely a function of his appetites and abilities, and is founded on self-service rather than a sense of moral obligation. In England, Lombroso's influence was limited and only Havelock Ellis seems to have given his anthropological theories any serious consideration (14). This brief history will resume with the development of the modern psychopathy concept, but first I will present an outline of how this idea of the amoral individual was fairing in legal contexts, where some of the most heated debate was generated and where the scientific status of psychiatric concepts was open to direct professional critique.

\section{The legal background}

That the problem of psychopathy is brought into sharp focus when medical and legal conceptual frameworks wrestle with it in the forensic context is particularly true when the case is one of homicide. A famous Victorian example is provided in $R v$ Dove (1856), in which strong medical evidence of insanity was rejected by the judge in favour of an explanation in terms of wickedness. Roger Smith captured the essence of the defence case when he said that 'Medical witnesses admitted under cross-examination that there was every indication that Dove could distinguish right from wrong; they suggested, however, that this knowledge would not have informed his deed' (15). The judicial response here indicates the trend in such cases at this time, and many more could be adduced which involve alienists arguing for moral insanity but the court favouring an explanation of the offence in terms of depravity. Courts, and juries in particular, founded their decisions on prevailing commonsense notions of morality, responsibility, and justice, and disregarded medical evidence as irrelevant or misguided. These notions gradually came to acknowledge that society subsumes a number of people for whom moral sensitivity may be regarded as absent, even though the ability to appreciate the demands of law is present.

This constituted an increasingly explicit problem and, over the years, generated a number of important judicial statements, in particular those in $R v$ Davis (1881), $R v$ Fryer (1914), $R v$ Codere (1916), and most significantly, $R v$ Windle (1952). The concept received attention in the criminal law only in relation to the M'Naghten Rules and insanity pleas, until the Homicide Act of 1957 elaborated the notion of 'abnormality of mind' and allowed for a plea of diminished responsibility. There are also, of course, corresponding developments in statute law, from the Mental Deficiency Acts of 1913 and 1927 to the Mental Health Act of 1959, and these have been amply examined elsewhere $(10,16)$.

In the cases of $R v$ Heath (1946), often taken as an epitome of criminal psychopathy, and of $R v$ Straffen (1952), medical testimony to the effect that the defendants lacked any signs of moral sensibility, or conscience, and were thus unable to empathise or experience remorse, was countered by prosecution evidence that they could nevertheless distinguish right from wrong. The trial transcripts in such cases illustrate that the juxtaposition of the conceptual frameworks of the medical and legal professions continued to produce anomalies $(17,18)$, and appear at times to be so different as to be incommensurate $(5,19)$.

The infamous case of $R v$ Byme (1959) is a significant contribution to both legal and popular notions of psychopathy. The accused had killed and mutilated a young nurse, then given himself up to the police some three weeks later. He was described by medical witnesses as a 'sexual psychopath', a wide-ranging and now obsolete term borrowed from American psychiatry, by which they meant a person subject to violent 'perverted' sexual desires which he finds difficult or impossible to control. The condition constituted, they suggested, an abnormality of mind within the terms of the Homicide Act (1957). The Appeal Judge's subsequent statement as to the import of 'abnormality of mind' provided for diminished responsibility founded on 'irresistible impulse' so stoutly resisted for so many years and strongly rejected in a number of notable cases (20).

In spite of this development, juries generally 
preferred to reject manslaughter pleas founded on evidence of psychopathy alone, including cases of irresistible impulse, continuing to employ 'lay' notions of responsibility and illness (21). For such a plea to be successful, it was necessary that the defendant suffer from some additional abnormality such as epilepsy or bizarre sexual deviation, and whereas legal authorities had previously tended to concur with juries in psychopathy cases, they were now obliged to moderate their views and many murder decisions were reduced to manslaughter on appeal (22). As the practicalities and implications of the new Act became apparent, the trend towards a wide definition of the grounds for diminished responsibility was matched by an increasing tendency, from about 1965 onwards, for cases involving psychopathic disorder (by then defined in the Mental Health Act of 1959) to end in a prison sentence rather than a secure hospital placement, unless the offender was acknowledged to be suffering from some additional mental disorder $(23,24)$. Susan Dell has pointed out that some of the anomalies she perceives in the operation of Section 2 of the Homicide Act result from 'doctors opining not on medical but legal and moral aspects' (25), and clearly, when it comes to homicides involving psychopaths, the psychiatrist is caught between Scylla and Charybdis: if they cling steadfastly to the scientific, deterministic medical dialogue they risk being ignored or dismissed as irrelevant, and if they enter into the legal and moral dialogue they risk the charge of having no more authority in these matters than the layperson. This was the problem in moral insanity trials of the last century, and it remains the problem in psychopathy cases today.

\section{The modern concept of psychopathy}

In America, the concept of moral insanity became a 'waste-basket' for unclassifiable conditions, but was eventually transmuted into 'sociopathy' by Partridge and in 1930 defined by him as 'deviated or pathological social relations' (26). For many contemporary psychiatrists it was synonymous with criminal recidivism or any form of persistent antisocial behaviour, and throughout the 1940s Karpman made determined efforts to narrow it down by setting aside what he considered to be diagnostically distinct conditions, and suggesting that the residual characteristics could be accounted for as the sequelae of an innate incapacity for the development of conscience (27). True psychopaths were distinguished by absence of mental conflicts, of remorse, of empathy, and of guilt-feelings, that is of all the experiential accoutriments of conscience, and were to be differentiated from symptomatic psychopaths (in which psychopathy is a description applied as a result of some other disorder) on these grounds. This typology has since received much empirical support and a great deal of subsequent research and literature is confounded by failing to take it into account. This problem is compounded a) by the adoption of a concept founded on the antisocial personality disorder as described in the Diagnostic and Statistical Manuals of the American Psychiatric Association, most recently in the revised 3rd edition of 1987, 'DSM-III-R' (28), b) by focusing almost exclusively on the inmates of prisons or secure psychiatric facilities (29), and c) by ignoring the long tradition, acknowledged in the typologies of Henderson (30) and Cleckley (31), of including in the category certain non-criminal, socially successful individuals - the 'successful psychopath'. There are some notable exceptions (32), but one of the major texts, the Hare and Schalling symposium of 1978 (33) is guilty on all counts, and this leads to a number of explicit internal contradictions (when Cleckley's concept is used as a starting point, for example, in the contribution by Spielberger). One contributor, Widom, has acknowledged point $b$ ) above and has made continuing efforts to study alternative samples (34). Indeed, Hare himself has criticised psychopathy research on the same ground (35), although he paradoxically goes on to repeat the error in his subsequent work (36).

Theories focusing on 'sensation-seeking' (according to which the psychopath is hyposensitive to, and therefore seeks an unusually high degree of, arousing stimuli) in particular those of Quay (37) and Zuckerman (38), have yielded contradictory results (39), and incorporate the shortcomings noted above. One consistent finding, however, is that samples tend to comprise at least two distinct subgroups, one characterised by impulsivity, high anxiety and poor social functioning, the other by emotional detachment, absence of anxiety and of mental conflict, and welldeveloped social skills - lending support to Karpman's typology. The extensive researches by Blackburn have uncovered similar sub-groupings (40) but employ samples drawn from a highly selected group of patients and offenders.

Doren (41) has recently attempted to integrate the most persistent findings from the major theories of psychopathy into a single coherent theory, but in doing so simply compounds their respective weaknesses. He assumes that the 'psychopathy' referred to by each theorist is the same concept, posits a theory in terms of psycho-physiological causal mechanisms, overlooks the socio-political aspects of psychopathy (for example as 'deviance'), and ignores the long-established notion of the cool, calculating, manipulative, successful psychopath, concentrating exclusively on the various forms of antisocial personality. Thus, he accepts Gough's depiction of the psychopath as deficient in role-taking ability (42) in the sense of being able to predict and respond appropriately to the reactions of other people. Certainly, in some instances the callous responses of criminal psychopaths may suggest a deficit of this type, but many other psychopaths are remarkable for their finesse in anticipating and thereby manipulating the complex reactions of other people, and their ability to utilise this skill remorselessly to their own advantage. The individual who most closely matches Gough's characterisation is surely the isolated 
schizoid, who feels cut off from other people, cannot identify with them and therefore renounces competitively secured goals in favour of a solitary lifestyle, rich in fantasy and prone to depressive reactions (not at all characteristic of primary psychopaths).

In contrast to those researchers who have adopted a broad DSM-III approach to defining their samples, Wishnie (43) has differentiated the impulsive personality' from other types of personality disorder and actually describes, under this rubric, the anxious, secondary (or symptomatic) psychopath separated out by Karpman. He admits he is 'at a loss' when faced with the cold, callous type of psychopath, and in good psychoanalytic tradition attributes his acute discomfort to the subconscious recognition of his own latent destructiveness. What marks out this 'true' psychopath, and what Wishnie admits is the really frightening aspect, is not the psychopath's potential for, or even commission of, horrifying acts, but rather his total lack of compunction or consequent moral emotion. This I take to be the distinguishing feature of true psychopathy, founded on an absence of conscience and nicely captured in the phrase used by defence counsel to describe Neville Heath (44), 'a quiet sort of detachment'. In fact, 'inability to experience guilt' has long been regarded by some researchers, such as Maher (33) and the McCords (45), as the major single characteristic of psychopaths. Davies and Feldman (46) found that British psychiatrists demonstrated greater agreement over this than over any other of 22 key diagnostic signs, and in 1982 McCord (47) concluded after a lifetime of research that many conditions hitherto associated with psychopathy should be regarded as distinct and separate, and that once these are excised we should consider the true psychopath to be characterised by a lack or absence of conscience. Reid (48), in his text of 1986, comes to a similar conclusion.

\section{The successful psychopath}

If I am right that psychopathy is, in some sense yet to be delineated, equatable with absence of conscience, it does not follow that psychopaths will inevitably be antisocial, aggressive, impulsive, inadequate or criminal, as assumed in the DSM concept. Indeed, it might suggest that some are enabled thereby to function more effectively, in some circumstances, than those of us constrained by moral principles and sensitivities, and I will now briefly review the support for this suggestion beginning with a consideration of the psychopath's manipulative skills, and using various recent proposals as a foil against which to illustrate my point.

Concerning the manipulativeness of the psychopath, Person (49) claims that this is actually pathological in itself because it has become obligatory rather than existing as an option, and is aimed at allaying otherwise uncontrollable deep-seated anxiety and depression. The weight of evidence (50) is actually that true, or 'primary', psychopaths do not exhibit signs of underlying anxiety or mental conflicts, this being the characteristic which distinguishes them from secondary psychopaths. She claims that their manipulations are inevitably self-defeating but gives no indication of how this might be substantiated. In seeking to contrast the psychopath's behaviour with that of the entrepreneur, whom she defines as a successful manipulator, Person fails to recognise the ubiquity of such skills in everyday social transactions (51), and provides no account of how the two groups may be distinguished conceptually, or empirically, from the rest of the population. Indeed, the evidence is that psychopaths cannot be empirically differentiated from other manipulative people (52). Detailed refutation of her claim that psychopaths cannot be successful is difficult because of her failure to specify a concept of 'success' in this context. This is particularly unfortunate since the issue is already complicated by the idiosyncratic ordering of personal values which is consequent upon the psychopath's self-centredness and lack of moral concern. Finally, at no point does Person say what she means by the term 'psychopath' or recommend any research strategies which might produce data to support her claims.

I would venture that the critical difference between psychopaths and other manipulative people does not concern the degree of 'success' they enjoy, but rather the fact that the true psychopath is not constrained by the moral considerations which normally contribute to the regulation of interpersonal behaviour. He may feign moral sensitivity, and such regulation has been shown to comprise a series of conventions, or protocols (53), which may be learnt, copied and utilised without genuine conviction. The psychopath's manipulations are based on a lack of respect for the moral claims of others. Since he is unfettered by the effects of conscience, he feels quite at liberty to ignore such claims and use people for his own ends without let or hindrance, and in this he may be as successful or unsuccessful as the next person.

Admittedly, the successful, manipulative psychopath is an elusive subject for research, since absence of conscience does not preclude the development of prosocial behaviour or any of the qualities which facilitate personal achievement in many societies. Indeed, a number of significant contributors to the psychopathy literature (54) claim that psychopathy is an adaptive response to modern social pressures, and facilitates more effective social performance and attainment of personal objectives. Writing in 1972, Harrington (55) elaborated this view and conceived it as indicative of a new post-moral era in American society. Robert Smith (56) suggests that this interpretation of psychopathy, with which he concurs, has been slow to surface because of the disinclination to see it among the cultural or economic elite. In a society which emphasises material success, rewards uncompromising competitiveness, and admires rugged individuality ('the man who knows what he wants and goes out and gets it', 'the man who does his 
own thing'), the psychopath as conceptualised by Smith is exquisitely adapted to succeed. He is the logical endpoint of society's real value-orientation. He may ultimately be successful or unsuccessful, criminal or non-criminal, impulsive or calculating: it is his lack of moral scruple which sets him apart, his lack of conscience.

This perspective is echoed more recently in a review of sociological approaches, by Sanchez (57), which acknowledges that the non-criminal psychopath's talent for impression management, calculation and charm make him difficult to distinguish since we all possess these to some extent. In truth, some psychopaths have an ability to convince, persuade and talk their way out of difficult situations which is almost beyond belief (58), and even McCord himself admits that he has been fooled into recommending the release of individuals who have gone on to commit further serious crimes (47). Treves-Brown (59) and Whitehead (60) are among many British psychiatrists who find the psychopath's lovelessness and absence of guilt-feelings reminiscent of many powerful leaders in industry, the armed forces and government, and his superficial charm coupled with utter unreliability and incorrigibility 'familiar to us all from politicians' (61). Finally, it is worth noting that Herschel Prins's latest statement of his 'socio-forensic' approach has remained virtually unchanged from his 1980 text (62), except he adds that the category 'essential psychopath' 'might also include those ruthless businessmen and women and politicians who trample on others to fight their way to the top' (63).

\section{Some tentative conclusions}

The concept of psychopathy outlined, abstracts the features common to its clinical and legal history, and is consistent with a vast amount of empirical research. It is supported by findings confirming lack of guilt feeling and empathy in psychopaths (64), by clinical observations of psychopaths (65), and by a vast array of biographical and autobiographical material (66). In light of this, we must consider whether psychopathy could ever be posited within a traditional psychiatricmedical framework (and its gradual displacement by broader DSM-III type diagnostic categories suggests that this has, to some extent, been acknowledged), and whether a more flexible and accurate formulation than is possible in terms of either medicine or law may be provided by viewing it as an ethical category. This will entail asking whether we ought to regard psychopathy as an illness, and whether it is an appropriate arena for psychiatic intervention, be it diagnostic, therapeutic or forensic.

Illness may be regarded as largely a socially defined phenomenon (67), and illness-ascription (as opposed to formal diagnosis) a judgement exercised by all members of society regardless of their inexpertise (68). Whereas mental illness occupies an eccentric position in relation to the criteria adopted in the public definition of the sick role (69), psychopathy, if we are to consider it as amounting to absence of conscience, falls outside them altogether, and on the basis of lay theories of illness (70) it might even be construed as the epitome of health, because empirical evidence (71) consistently identifies self-determination, self-control and freedom from mental conflict as major components of lay conceptions of health, and these features are associated with 'primary' psychopathy as defined in the literature (72), as well as consistent with the amoral personality, particularly the 'successful psychopath' sketched above. In other words, absence of conscience fails to merit the public ascription of illness. Efforts on the part of psychiatrists to substantiate an illness model of psychopathy in forensic contexts, where the alternative conceptual frameworks are clearly juxtaposed and seek common ground, have generated little public approval and, indeed, diminishing jurisprudential support (witness the rapid return to a retributive approach in the disposal of psychopathic homicides under Section 2 of the Homicide Act (73), and the resistance to any extension of the diminished responsibility plea beyond homicide cases (74)), although it must be noted that an increasing proportion of homicide cases evoke a successful diminished responsibility finding, often including cases previously included under the insanity provisions (75). This suggests that the circumstances surrounding homicide often entail conditions contributing to diminution of responsibility, and that the psychopath is not being dealt with through Section 2 simply in virtue of his/her psychopathy.

How can we reconcile the courts' increasing willingness to accept the evidence in support of diminished responsibility and to accept that plea, with a corresponding willingness to send offenders to prison rather than provide for placement in secure psychiatric facilities? The salience of this apparent anomaly has led some writers to suggest that it could reflect the courts' sensitivity to the lifelong stigma attached to a conviction for murder, as if a finding of manslaughter on grounds of diminished responsibility were somehow more socially acceptable (76). It is more plausible to conclude that whilst largely based on medical evidence, a diminished responsibility finding represents the court's interpretation of that evidence in terms of its moral significance in the light of the legal requirement contained in Section 2 of the Act. That legal requirement concerns the relationship between 'abnormality of mind' (a medical concept) and 'mental responsibility' (a moral concept). As Bavidge says: 'The psychological states and capacities that psychiatrists report on provide grounds for decisions about responsibility only when they are subsumed into the moral domain' (77). How this is done remains obscure, however, and as noted previously, medical evidence is quite likely to be considered irrelevant or else the witness is reluctantly drawn out of his/her area of expertise and into an explicitly moral debate. Nevertheless, the decision as to the responsibility of psychopathic offenders remains a moral, not a medical, 
issue, and the problem now becomes one of sentencing policy in light of a diminished responsibility finding.

The judge, having heard the medical evidence and ruled in favour of diminished responsibility, may make provision for the offender to receive psychiatric treatment, or may impose a prison sentence. In choosing the latter, the judge explicitly rejects the appropriateness of medical treatment. In cases of psychopathy, this could be understood simply as a pragmatic response to the 'untreatability' of the condition and the dangerousness of the offender. If 'treatability' were the criterion, however, the injustices and anomalies which would arise would be intolerable (consider, for example, the 'treatability' of some psychoses) and, concerning 'dangerousness', as far as protecting the public goes it is actually one of the advantages of a hospital placement that, unlike a prison sentence, it may continue indefinitely providing certain criteria are satisfied. On balance it seems more likely that, in sending psychopaths to prison, the courts are rejecting the appropriateness of treatment and with it an illness model of psychopathy.

If psychopathy is best regarded as a moral category, framed in terms of goodness, badness, obligation and other ethical concepts, can it not also be a psychiatric matter? What if it is thought to be the result of an unequivocally medical condition, such as a brain tumour? I don't think this example extends the argument. Certainly, the tumour is a matter for medical/psychiatric expertise, but the question as to the appropriateness of bringing such expertise to bear on the moral component remains unchanged. Of course it has been argued, most vociferously by its critics, that traditional psychiatry is in any case a 'moral enterprise': some argue that this is the result of the socio-political history of medicine in general, and psychiatry in particular (78), others that it is just one consequence of the impossibility of value-free medicine (79); some believe that it is best acknowledged and embraced through a reconstruction of psychiatric epistemology (80), whilst others eschew it as a dangerous tendency to be held in check by striving for a positivistic ideal (81). Writing on the notion of 'moral insanity', Ellard poses the question why medicine invents 'entities which we place in people's heads and then use as explanations', and acknowledges that 'ignorance is uncomfortable: if we can offer no satisfying reasons for some people being much more wicked than others, placing them in a category and giving it a name may get us by until we can do something better' (82). Though a point wellmade, I think it is even more pertinent to ask why that category should be a medical one. Truly, ignorance is sometimes uncomfortable, but it may also provide a fertile medium in which to sow the seeds of professional aspiration, and for the alienists of the last century those seeds produced an impression of expertise, which led to claims of authority, and with it the substantiation of professional power and prestige. In the case of psychopathy, the fruits of this process have included not only the expansion of forensic psychiatry, but also an abundance of confusion, most notably in the minds of social administrators, legislators, the police, the judiciary, and health care workers. Ultimately it has served to undermine the prestige of psychiatry, because it has served to highlight major differences over fundamental conceptual and definitional issues as well as diagnostic practices.

It has also seduced psychiatry to run counter to society's illness-ascription practices, as well as to 'commonsense' notions of moral responsibility and justice. In conclusion, therefore, it would appear that psychiatry might usefully admit that it has made some kind of 'category mistake' as far as psychopathy is concerned, and consign the whole concept to the labyrinthine procrastinations of moral and legal philosophers.

Colin A Holmes RMN, BA(Hons), RNT, MPhil is Lecturer/Clinician in the School of Nursing at Deakin University, Geelong, VICTORIA 3217, Australia.

\section{References}

(1) Gunn J, Robertson G. Psychopathic personality: a conceptual problem. Psychological medicine 1976; 6: 631-634. Mawson A, Mawson C. Psychopathy and arousal: a new interpretation of the psychophysiological literature. Biological psychiatry 1977; 12, 1: 49-74. Hare R, Schalling D, eds. Psychopathic behaviour: approaches to research. New York: John Wiley, 1978. Blackburn R. Personality and the criminal psychopath: a logical analysis and some empirical data. In: Facolta di Giurisprudenza, University of Messina, eds. Lo psicopatico delinquente. Milan: Giuffre, 1980. Davies W, Feldman $P$. The diagnosis of psychopathy by forensic experts. British journal of psychiatry 1981 ; 138: 329-331. Prins H. Dangerous behaviour, the law and mental disorder. London: Tavistock, 1986. Grounds A, et al. An in-patient unit for 'psychopathic disorder' patients in $ᄋ$ Broadmoor Hospital. Medicine, science and law 1987; 27: 21-31.

(2) Werlinder H. Psychopathy: a history of the concepts. Uppsala: Almqvist and Wiksell, 1978.

(3) Rush B. Lecture on the mind, 1793. Reprinted in N Carlson E, et al, eds. Benjamin Rush's lectures on the mind. N Philadelphia: Philosophical Society, 1981.

(4) Prichard J. A treatise on insanity and other disorders affecting the mind. London: Sherwood, Gilbert and Piper, 1835.

(5) Smith R. Trial by medicine. Edinburgh: Edinburgh $\stackrel{\infty}{+}$ University Press, 1981: 43.

(6) Kitching J. Lectures on moral insanity. British medical journal 1857; 1: 334-336, 389-391, 435-456.

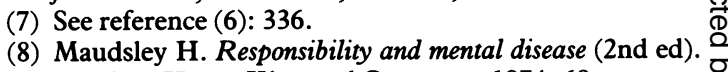
London: Henry King and Company, 1874: 68.

(9) Tredgold A. Mental deficiency (amentia) (1st ed). 8 London: Bailliere, Tindall and Cassel, 1908: 314.

(10) For an analysis, see Watson S. The moral imbecile: penal practice and psychiatric knowledge of habitual offenders, $\frac{\hat{O}}{7}$ 1913-1954. Unpub PhD thesis, University of Lancaster, 1988. 
(11) Fink A. Causes of crime: biological theories in the United States, 1800-1915. New York: Barnes and Company, 1938.

(12) Lombroso C. L'uomo delinquente. Milan: Hoepli,1876.

(13) Holmes C. The concept of psychopathy: an historical review and reformulation, with a consideration of implications for moral responsibility. Unpub MPhil thesis, University of Lancaster, 1988.

(14) Ellis H. The criminal (1st ed). New York: Scribner and Welford, 1890. Ellis himself became disillusioned by the time of the 4th edition of 1910 .

(15) See reference (5): 134-135.

(16) Walker N, McCabe S. Crime and insanity in England, vol. 2: new solutions and new problems. Edinburgh: Edinburgh University Press, 1973. Rollin H. The mentally abnormal offender and the law. Oxford: Pergamon, 1969. De Rueck A V S, Porter R, eds. The mentally abnormal offender. London: J and A Churchill, for the CIBA Foundation, 1969. Jacobs F. Criminal responsibility. London: London School of Economics with Weidenfeld and Nicholson, 1971. Some of the best discussions of the legislative developments may be found in the reports of the various review committees and royal commissions, including those of the Atkin Committee, Report of the Committee on Insanity and Crime Cmnd 2005, London: HMSO 1923, the Butler Committee, Report of the Committee on Mentally Abnormal Offenders Cmnd 6244, London: HMSO 1975, the Gowers Report, Report of the Royal Commission on Capital Punishment 1949-1953 Cmnd 8932, London: HMSO 1953, and the Percy Report Report of the Royal Commission on the Law Relating to Mental Disorder 1954-1957 Cmnd 169, London: HMSO 1957, and the Review of the Mental Health Act (1959) Dept of Health and Social Security, London: HMSO 1976.

(17) See, for example, reference (13): 59-70, Slater E. The M'Naghten Rules and the concept of responsibility. British medical journal 1954; 2: 7. Wootton B. Social science and social pathology. London: George Allen and Unwin, 1959; Williams G. Diminished responsibility. Medicine, science and law 1960; Oct: 41.

(18) See the symposium on forensic psychiatry in Fournal of medical ethics 1986; 12: 1: 5-31, in particular the contributions by Griew, Dell and Kenny, each of which points to anomalies in the practice implications of the Homicide Act.

(19) Smith R. Scientific thought and the boundary of insanity and criminal resposibility. Psychological medicine 1980; 10: 15-23. Expertise and causal attribution in deciding between crime and mental disorder. Social studies of science 1985; 15: 67-98. Criminal responsibility, psychiatry and history: three essays. Centre for Science Studies and Science Policy, University of Lancaster, 1988.

(20) See Lord Cooper's comments, for example, in $H M A v$ Braithwaite (1945); even after the Byrne case, irresistible impulse continued to be a poorly supported ground for a diminished responsibility plea, for example in $R v$ $M c$ Crorey (1962). See also, Minty L. Insanity and diminished responsibility as defences on criminal charges. Medico-legai journal 1961; 26: 134-143, 200208, and the comments of Samuels, cited by Prins $\mathrm{H}$. Offenders, deviants or patients? an introduction to socioforensic problems. London: Tavistock, 1980: 35. Note also the resistance to the notion of irresistible impulse in Scottish Law, evidenced in HMA v Carraher (1939) and confirmation in HMA $v$ Burnett (1963), and the unwillingness of English jurists to extend the notion beyond the case of homicide.

(21) Whitlock F. Criminal responsibility and mental illness. London: Butterworths, 1971; Minty L. Insanity and diminished responsibility as defences on criminal charges. Medico-legaljournal 1961; 134-143, and 200208.

(22) See reference (21) also, reference (17) Williams G.

(23) Dell S. The detention of diminished responsibility homicide offenders. British journal of criminology 1983; 23: 50. Dell S, Smith A. Changes in the sentencing of diminished responsibility homicides. British journal of psychiatry 1983; 142: 20-43.

(24) For a more complete account see Dell S. Murder into manslaughter: the diminished responsibility defence in practice. Oxford: Oxford University Press, 1985.

(25) Dell S. The mandatory sentence and Section 2. Fournal of medical ethics 1986; 12: 28.

(26) Partridge G. Current conceptions of psychopathic personality. American journal of psychiatry 1930; 87: 55.

(27) Karpman B. On the need of separating psychopathy into two distinct clinical types: the symptomatic and the idiopathic. Fournal of criminology and psychopathology 1941; 3: 112-137. Also, Conscience in the psychopath: another version. American journal of orthopsychiatry 1948; 18: 455-491.

(28) American Psychiatric Association. Diagnostic and statistical manual of mental disorders, (3rd ed) revised. Washington DC: American Psychiatric Association, 1987. See also, Millon T. Disorders of personality: DSM$I I I$, axis $I I$. New York: John Wiley, 1981, and Widiger T, Frances A, Spitzer R, Williams J. The DSM-IIIR personality disorders: an overview. American journal of psychiatry 1988; 145: 786-795.

(29) This is characteristic of most of the research, including that of Eysenck, Quay, Zuckerman, Blackburn, and Hare, and of the recent 'integrative' approach adopted by Doren. See reference (41).

(30) Adopted in the once standard psychiatry text, Henderson D, Gillespie R. A textbook of psychiatry for students and practitioners. London: Oxford University Press (4th ed), 1936, and elaborated by Henderson D, in his book Psychopathic states. New York: W W Norton, 1939.

(31) Cleckley H. The mask of sanity. St Louis: Mosby, lst ed 1941 , and 6th ed 1982.

(32) For example, Maher B. The principles of psychopathology. New York: McGraw-Hill, 1966, and the work of McCord W, culminating in his book, The psychopath and milieu therapy. New York: Academic Press, 1982.

(33) Hare R, Schalling D, eds. Psychopathic behaviour: approaches to research. New York: John Wiley, 1978.

(34) See reference (33): Widom C. A methodology for studying non-institutionalised psychopaths. Also, Widom C, Newman J. Characteristics of noninstitutionalized psychopaths. In: Farrington D, Gunn $\mathrm{J}$, eds. Aggression and dangerousness. New York: John Wiley, 1985.

(35) Hare R. Psychopathy. In: Venables P, Christie M, eds. Research in psychophysiology. New York: John Wiley, 1975, and again, see reference (33) Hare R, Cox D. Clinical conceptions of psychopathy, and the selection of subjects for research.

(36) Hare R. Twenty years of experience with the Cleckley psychopath. In: Reid W, ed. Unmasking the psychopath. New York: W W Norton, 1986.

(37) Quay H. Psychopathic personality in pathological 
stimulation-seeking. American journal of psychiatry 1965; 122: 180-183. See recent review in reference (41).

(38) Zuckerman $M$. Sensation-seeking and risk-taking. In: Izard C, ed. Emotions in personality and psychopathology. London: Plenum Press, 1979.

(39) See reference (13): 104-117, and recent summary in reference (41).

(40) Blackburn R. An empirical classification of psychopathic personality. British journal of psychiatry 1975; 127: 456 -460, and his Psychopathy, arousal and the need for stimulation, in reference (33). Also, Blackburn R. Personality and the criminal psychopath: a logical analysis and some empirical data. In: Facolta di Giurisprudenza, University of Messina, eds. Lo psicopatico delinquente. Milan: Giuffre, 1980. In his paper, On moral judgements and personality disorder: the myth of psychopathy revisited, delivered to the Annual Conference of the Northern Ireland Branch of the British Psychological Society, Donegal, Eire, May 1986, Blackburn asserts that the current conception of psychopathy remains 'little more than a moral judgement masquerading as a clinical diagnosis': 17.

(41) Doren D. Understanding and treating the psychopath. New York: John Wiley, 1987.

(42) Gough H. A sociological theory of psychopathy. American journal of sociology 1948; 53: 359-366.

(43) Wishnie H. The impulsive personality: a study in the management of destructive personality disorders. New York: Academic Press, 1977.

(44) See the chapter on Heath, in Clyne P. Guilty but insane. London: Nelson, 1973.

(45) McCord W, McCord B. Psychopathy and delinquency. New York: Grune and Stratton, 1956. McCord W, McCord B. The psychopath: an essay on the criminal mind. Princeton: Van Nostrand, 1964. More recently, McCord W. The psychopath and milieu therapy. New York: Academic Press, 1982.

(46) Davies W, Feldman P. The diagnosis of psychopathy by forensic experts. British journal of psychiatry 1981; 138: 329-331.

(47) See reference (45): McCord W.

(48) Reid W, ed. Unmasking the psychopath. New York: W W Norton, 1986.

(49) See reference (48): Person E. Manipulativeness in entrepreneurs and psychopaths.

(50) See reference (27): Karpman and reference (41): 96-98.

(51) See, for example, Knapp M et al. An exploration of deception as a communication construct. Human communication research 1974; 1:15-29 and the account in Schlenker B. Impression management. Monterey: Brookes-Cole, 1980, and the work on 'presentation of self' elaborated by Goffman $\mathrm{E}$ in the same book.

(52) For example, Smith R, Griffiths J. Machiavellianism and anomie. Psychological reports 1978; 42: 258, and the literature on 'Machiavellianism' in general.

(53) Semin G, Manstead A. The accountability of conduct: a social-psychological analysis. London: Academic Press, 1983.

(54) For example, Mailer N. The white negro. San Francisco: City Lights Books, 1957. Glenn M. The psychopath: hero of our age. Village voice 1967 Sept 14. Smith R J. The psychopath in society. New York: Academic Press, 1978. See also reference (55).

(55) Harrington A. Psychopaths. London: If Books, 1972.

(56) Smith R J. The psychopath in society. New York: Academic Press, 1978. Also, Smith R J. The psychopath as moral agent. Philosophical and phenomenological research 1984; XLV(2): 177-193, and Smith R J. The concept and measurement of social psychopathy. Fournal of research in personality 1985; 19: 219-231.

(57) See reference (48): Sanchez J. Social crises in psychopathy: toward a sociology of the psychopath.

(58) See, for example, the cases of Charles Sobhraj described in Thompson T. Serpentine. New York: Simon and Schuster, 1979; of Graham Young described in Holden A. Graham Young: the St Albans poisoner. London: Heinemann, 1974, and Rischmiller, reported in The Sunday Express 1983 Aug 21.

(59) Treves-Brown C. Who is the psychopath? Medicine, science and law 1977; 17, 1: 56-63.

(60) Whitehead J. Psychopaths in high places. World medicine 1974 Apr 7.

(61) See reference (59): 61.

(62) Prins H. Offenders, deviants or patients?: an introduction to socio-forensic problems. London: Tavistock, 1980.

(63) Prins H. Dangerous behaviour, the law and mental disorder. London: Tavistock, 1986.

(64) Starting with Lindner R. Experimental studies in constitutional psychopathic inferiority. Fournal of criminology and psychopathology 1943; 3: 252-276, and many others who used the Rorschach Test, through to Holzberg J, Hahn F. The picture-frustration test as a measure of hostility and guilt reactions in adolescent psychopaths. American journal of orthopsychiatry 1952; 22: 776-797, Maher's guilt assessments reported in reference (32), and Mosher's work using his own guiltassessment scale, reported in Mosher $\mathrm{D}$. The meaning and measurement of guilt. In: Izard C, ed. Emotions in personality and psychopathology. New York: Plenum Press, 1979. See reference (13): 144-145.

(65) For example, references (27), (31), (45), (46), (47), (48). Also, Thornton $\mathrm{N}$. The relationship between crime and psychopathic personality. Fournal of criminal law, criminology and police science 1951; 42: 199-204; Fotheringham J. Psychopathic personality: a review. Canadian Psychiatric Association journal 1957; 2: 52-74; Hare R. Psychopathy: theory and research. New York: John Wiley, 1970; Jensen O. The mask of psychopathy. International journal of law and psychiatry 1978; 1: 153166.

(66) Valuable bibliographies are provided in Lunde D. Murder and madness. San Francisco: San Francisco Book Company, 1976; Gaute J, Odell R. The murderer's who's who. London: Harrap, 1979, and see the bibliography of case material in reference (13). See also, Athens L. Violent criminal acts and actors: a symbolic interactionist study. London: Routledge Kegan Paul, 1980; Wilson C, Seaman D. Encyclopaedia of modern murder 1962-1983. London: Pan Books, 1986; Cameron D, Frazer E. The lust to kill: a feminist investigation of sexual murder. Cambridge: Polity Press, 1986; Babuta S, Bragard J C. Evil. London: Weidenfeld and Nicholson, 1988; and Holmes R, de Burger J. Serial murder. Newbury Park: Sage, 1988.

(67) Parsons T. The social system. Glencoe, Illinois: Free Press, 1951; Mechanic D. Medical sociology. New York: Free Press (2nd ed). 1978; Locker D. Symptoms and illness. London: Tavistock, 1981; Littlewood R, Lipsedge $M$. The butterfly and the serpent: culture, psychopathology and biomedicine. Culture, medicine and psychiatry 1987; 11: 289-336.

(68) Fabrega H. Disease and social behaviour: an interdisciplinary perspective. Cambridge, Mass: MIT Press, 1974. Note, however, the differences between 
disease and illness elaborated by Boorse C. What a theory of mental health should be. Fournal for the theory of social behaviour 1976; 6: 61-84, and Locker D. Symptoms and illness. London: Tavistock, 1981, and between these and 'sickness' described in Twaddle A. A sociology of health. St Louis: Mosby, 1977.

(69) Veatch R. The Medical Model: its nature and problems. Hastings Center studies 1973; 1: 59-76.

(70) Fitzpatrick R. Lay concepts of illness. In: Fitzpatrick R, et al. The experience of illness. London: Tavistock, 1984; Currer C, Stacey M, eds. Concepts of health, illness and disease. Leamington Spa: Berg, 1986.

(71) Crawford R. A cultural account of 'health'. In: McKinlay J, ed. Issues in the political economy of health care. London: Tavistock, 1984. This is a form of eudaimonistic model, as described in the typology of Smith J. The idea of health: a philosophical enquiry. Advanced nursing science 1981; Apr: 43-50. See also, Dubos R. Health and Creative Adaptation. Human nature 1978; 1: 74-82.

(72) See references (27), (41), (50), (52).

(73) See references (23), (24).

(74) See reference (20), and note the unwillingness of countries which already have the diminished responsibility pleas to broaden its application in homicide cases, or to extend it to other offences, including attempted homicide. See, for example, Campbell I. Mental disorder and criminal law in Australia and New Zealand. Sydney: Butterworths, 1988, and the Law Reform Commission of Victoria. Discussion paper no 14: mental malfunction and criminal responsibility. Melbourne: Law Reform Commission of Victoria, 1988.

(75) Sparks R. Diminished responsibility in theory and practice. 27 Mod LR 31-2, 1964; Walker N, McCabe S. Crime and insanity in England, vol 2: new solutions and new problems. Edinburgh: Edinburgh University Press, 1973. Butler Committee. Report of the Committee on Mentally Abnormal Offenders Cmnd 6244. London: HMSO, 1975, Appendix 9; the Advisory Council on the Penal System. Sentences of imprisonment: a review of maximum penalties. London: HMSO, 1978; Ashworth A, Shapland J. Psychopaths in the criminal process. CLR 272-276, 1980. Dell S. Wanted: an insanity defence that can be used. CLR 431, 1983.

(76) Law Reform Commission of Victoria. Discussion paper: homicide. Melbourne: Law Reform Commission of Victoria, 1988: paras 105-108.

(77) Bavidge M. Mad or bad? Bristol: Bristol Classical Press, 1989: 79.

(78) Such as the so-called 'antipsychiatry' group, including Laing, Goffman, Szasz, and Cooper, whose observations are nicely summarised in Sedgwick P. Psychopolitics. London: Pluto Press, 1982. See also, Ingleby D, ed. Critical psychiatry: the politics of mental health. Harmondsworth: Penguin Books, 1980 (particularly
Ingleby's own contribution); Conrad P, Schneider J. Deviance and medicalization. New York: Merrill, 1980, and for a wideranging sociological critique see Cohen $S$, Scull A, eds. Social control and the state. Oxford: Blackwell, 1985.

(79) For example, Fabrega H. Psychiatric diagnosis: a cultural perspective. Fournal of nervous and mental diseases 1987; 175: 383-394, and Fabrega H. An ethnomedical perspective of Anglo-American psychiatry. American journal of psychiatry 1989; 146, 5: 588-596.

(80) In addition to the work of Szasz see, for example, Sarbin T, Mancuso J. Schizophrenia: medical diagnosis or moral verdict? New York: Pergamon Press, 1980; Walker C. Philosophical concepts and practice: the legacy of Karl Jasper's psychopathology. Current opinion in psychiatry 1988; 1: 624-629; Gellner E. The psychoanalytic movement. London: Paladin Books, 1985.

(81) For example, Will D. Transcendental realism and the scientificity of psychoanalysis. Fournal of medical psychology 1983; 56: 371-378. Will D. The progeny of positivism: the Maudsley School and antipsychiatry. British journal of psychotherapy 1984; 1: 50-67; Ebmeier K. Explaining and understanding in psychopathology. British journal of psychiatry 1987; 151: 800-804; Hafner H. The concept of disease in psychiatry. Psychological medicine 1987; 17: 11-14; Wallace E. Philosophy of psychiatry: general issues. Current opinion in psychiatry 1988; 1: 617-623.

(82) Ellard J. The history and present status of moral insanity. Australian and New Zealand journal of psychiatry 1988; 22: 383-389.

\section{Cases cited}

HMA v Braithwaite (1945): reported in Gordon G H. Criminal law. Edinburgh: Scottish Universities Law Institute, 1978; also in Card R. Cross and fones cases and statutes on criminal law (6th ed). London: Butterworths, 1977. HMA v Burnett (1963): reported in Gordon G H. Criminal law, as above.

HMA v Carraher (1939): as above.

R v Byrne (1959): 44 Cr App R 246.

R v Codere (1916): 12 Cr App Rep 21.

$R$ v Davis (1881): 14 Cox CC 563; also reported in reference (5).

$R$ v Dove (1856): reported in reference (5).

R v Fryer (1915): 24 Cox CC 403.

$R$ v Heath (1946): reported in reference (44).

$\mathrm{R} v$ McCrorey (1962): reported in Hollis C. The homicide act. London: Gollancz, 1964.

$R$ v Straffen (1952): reported in Fairfield L, Fullbrook E. The trial of Fohn Thomas Straffen. Notable British Trials series. London: Hodge, 1954.

R v Windle (1952): 2 QB826, 833. 